\title{
Growth hormone deficiency and combined immunodeficiency
}

\author{
Mimi L K Tang, Andrew S Kemp
}

\begin{abstract}
The first description of an association of isolated growth hormone deficiency (IGHD) and combined immunodeficiency is presented. The findings suggest that IGHD should be considered as a cause of short stature in children with combined immunodeficiency before attributing growth retardation to infection.
\end{abstract}

(Arch Dis Child 1993;68:231-2)

There have been several reports of isolated growth hormone deficiency (IGHD) associated with $\mathrm{X}$ linked agammaglobulinaemia. ${ }^{1-3}$ In these cases cellular immune function, as measured by mitogenic responses and $T$ cell numbers, has been normal. We describe a patient with a combined defect in humoral and cellular immunity associated with IGHD whose immune defect was inherited in an X linked recessive pattern.

\section{Case report}

A boy was born at full term to unrelated parents. Recurrent respiratory tract infections with cough and purulent nasal discharge, episodes of conjunctivitis, pustular lesions on his fingers and toes, and candida napkin dermatitis commenced at 6 months of age. At 8 months, a seborrhoeic scalp rash was noted. At 9 months, he developed a Haemophilus influenzae $B$ arthritis of his knee. Serum immunoglobulin concentrations showed absent IgG, normal IgA, IgM, and IgE (table). He was treated with intravenous antibiotics and gammaglobulin, and was continued on monthly immunoglobulin infusions with antibiotics during periods of productive cough. Immune function tests at 11 months revealed a combined defect of humoral and cellular immunity (table).

He was admitted to hospital at 4 years of age having had a persistent cough for 18 months with deterioration over the preceding eight weeks despite regular oral antibiotics. He had not suffered from recurrent otitis media, mucocutaneous candida, or chronic diarrhoea. Examination of his chest revealed bilateral basal crackles, and a chest radiograph demonstrated bilateral basal consolidation with right middle lobe and left lingular collapse. Bronchoscopy and bronchial aspirate failed to identify a causative organism. A lymphopenia and a neutropenia were noted for the first time. Mitogenic responses and $T$ cell numbers had deteriorated (table). He improved slowly over five weeks with intensive physiotherapy, inhaled salbutamol, and intravenous antibiotics. Subsequent management has included prophylactic antibiotics and monthly gammaglobulin infusions. He continues to have an intermittent unproductive cough and has developed mild persistent oral thrush.

The patient's height and weight at 10 months of age were on the 10th centile. At 2 years of age
Department of

Immunology,

Royal Children's

Hospital,

Victoria,

Australia

Mimi L K Tang

Andrew S Kemp

Correspondence to:

Dr Mimi Tang,

Department of Immunology,

Royal Children's Hospital,

Flemington Road,

Parkville,

Victoria 3052 ,

Australia.

Accepted 10 October 1992

Immune function tests (normal range for age in parentheses)

\begin{tabular}{|c|c|c|c|c|c|}
\hline & \multicolumn{5}{|l|}{ Age (months) } \\
\hline & 9 & 11 & 51 & 60 & 63 \\
\hline $\begin{array}{l}\text { White cells }\left(\times 10^{9} / 1\right) \\
\text { Lymphocytes }\left(\times 10^{9} / 1\right)\end{array}$ & $\begin{array}{r}28 \cdot 0 \\
2 \cdot 0\end{array}$ & $\begin{array}{r}12 \cdot 7 \\
2 \cdot 0\end{array}$ & $\begin{array}{l}1.0 \\
0.7\end{array}$ & $\begin{array}{l}9 \cdot 2 \\
0 \cdot 9\end{array}$ & $\begin{array}{r}10 \cdot 2 \\
1 \cdot 0\end{array}$ \\
\hline $\begin{array}{l}\text { Immunoglobulins }(\mathrm{g} / \mathrm{l}) \\
\text { IgG } \\
\text { IgM } \\
\text { IgA }\end{array}$ & $\begin{array}{l}0.5(2 \cdot 4-11 \cdot 3) \\
0.4(0.3-1 \cdot 3) \\
0 \cdot 2(0 \cdot 1-0 \cdot 9)\end{array}$ & $\begin{array}{r}22 \cdot 7(2 \cdot 4-12 \cdot 0) \\
0 \cdot 3(0 \cdot 3-1 \cdot 5) \\
<0 \cdot 1(0 \cdot 1-1 \cdot 1)\end{array}$ & $\begin{array}{c}10 \cdot 2(4 \cdot 8-17 \cdot 7) \\
0 \cdot 1(0 \cdot 3-1 \cdot 5) \\
0 \cdot 4(0 \cdot 3-2 \cdot 1)\end{array}$ & $\begin{array}{r}7 \cdot 7(4 \cdot 8-17 \cdot 7) \\
0 \cdot 4(0 \cdot 3-1 \cdot 5) \\
<0 \cdot 1(0 \cdot 3-2 \cdot 1)\end{array}$ & $\begin{array}{l}8 \cdot 4(4 \cdot 8-17 \cdot 7) \\
0 \cdot 4(0 \cdot 3-1 \cdot 5) \\
0 \cdot 1(0 \cdot 3-2 \cdot 1)\end{array}$ \\
\hline $\begin{array}{l}\text { Isoagglutinin titres* } \\
\text { Anti-A } \\
\text { Anti-B }\end{array}$ & $=$ & $\begin{array}{l}2 \\
0\end{array}$ & $=$ & $\bar{z}$ & $\begin{array}{l}\mathbf{0} \\
\mathbf{0}\end{array}$ \\
\hline $\begin{array}{l}\text { Lymphocyte subsets }\left(\times 10^{9} / 1\right. \\
\text { CD3 } \\
\text { CD4 } \\
\text { CD8 } \\
\text { CD19 }\end{array}$ & $\bar{z}$ & $\begin{array}{l}0.85(2 \cdot 7-8 \cdot 5) \\
0.49(1 \cdot 7-5 \cdot 7) \\
0.12(0 \cdot 6-2 \cdot 7) \\
1 \cdot 18(0 \cdot 7-3 \cdot 4)\end{array}$ & $\begin{array}{l}0.09(2.0-5 \cdot 3) \\
0.07(0.7-2.0) \\
0.03(0.5-1.4) \\
0.58(0.5-1.5)\end{array}$ & $\begin{array}{l}0.07(1 \cdot 1-3.5) \\
0.07(0.7-2.0) \\
0.04(0.5-1.4) \\
0.79(0.5-1.5)\end{array}$ & $\begin{array}{l}0.19(1 \cdot 1-3 \cdot 5) \\
0.08(0 \cdot 7-2 \cdot 0) \\
0.05(0.5-1 \cdot 4) \\
0.94(0.5-1 \cdot 5)\end{array}$ \\
\hline $\begin{array}{l}\text { Mitogen responses (\%)† } \\
\text { Whole blood: } \\
\text { Phytohaemagglutinin } \\
\text { Separated cells: } \\
\text { Phytohaemagglutinin } \\
\text { Pokeweed mitogen } \\
\text { Concanavalin A }\end{array}$ & $\begin{array}{l}- \\
=\end{array}$ & $\begin{array}{r}31 \\
11 \\
83 \\
1\end{array}$ & $\begin{array}{l}17 \\
= \\
=\end{array}$ & $\begin{array}{l}25 \\
47 \\
79 \\
60\end{array}$ & $\begin{array}{r}19 \\
55 \\
55 \\
9\end{array}$ \\
\hline
\end{tabular}

${ }^{*}$ Blood group $\mathrm{O}$

†Mitogenic responses expressed as a percentage of control; normal range $70-150 \%$. 
his height was on the 25 th centile $(84 \mathrm{~cm})$ and weight on the 10th centile. His growth velocity then fell to $4 \mathrm{~cm} /$ year and his height at 4 years was below the 3 rd centile $(93.3 \mathrm{~cm})$. Bone age at 3.5 years was $2-2.75$ years, and at 4.25 years was 3.0 years. Penile length was $5 \mathrm{~cm}$ (50th centile). Neurological examination was normal. Concentrations of urea and electrolytes and a lateral skull radiograph were normal. The father's height was on the 50th centile and mother's height was on the 25 th centile. Thyroid function was normal for age with total thyroxine concentration $142 \mathrm{nmol} / \mathrm{l}$ (reference range 70-155), free thyroxine index 105 (60-155), triiodothyronine resin uptake $74 \%(75-115)$, and thyroid stimulating hormone $2 \cdot 2 \mathrm{mU} / 1(<5 \cdot 0)$. An arginine-insulin tolerance test revealed complete growth hormone deficiency (peak growth hormone $4.5 \mu \mathrm{g} / \mathrm{l}$, normal peak >10 $\mu \mathrm{g} / \mathrm{l})$. His glucose concentration fell from $3.6 \mathrm{mmol} / 1$ to $0.9 \mathrm{mmol} / 1$ and cortisol rose from $390 \mathrm{nmol} / 1$ to $988 \mathrm{nmol} / \mathrm{l}$ during the study. He was commenced on human growth hormone at 4.5 years of age. He has since grown $5 \cdot 2 \mathrm{~cm}$ in six months.

Immune function tests at 4.9 and 5.2 years showed a persistent $T$ cell defect (table). The normal concentrations of IgM on these occasions did not appear to be related to growth hormone treatment as normal concentrations had been noted previously. In vitro culture of separated lymphocytes at $5 \cdot 2$ years with recombinant growth hormone at $10 \mu \mathrm{g} / \mathrm{ml}$ and $100 \mu \mathrm{g} / \mathrm{l}$ did not improve mitogenic responses. Adenosine deaminase and purine nucleoside phosphorylase values and expression of class 1 and class 2 major histocompatibility complex antigens were normal.

\section{FAMILY HISTORY}

The patient has two sisters aged 5 years and 9 years who are both well. There were no early child deaths in the immediate family. His mother had two brothers who both died in the first year of life with 'immunoglobulin deficiency'. His mother's uncle, one of twins, died at 9 months of age with influenza. The other twin died of a carcinoma at the age of 65 years.

\section{Discussion}

We present the first description of a combined immune defect in association with IGHD. Based on family history, the immune defect in our patient appears to be inherited in an $\mathrm{X}$ linked recessive fashion. There is a range of immunological findings and severity in $\mathrm{X}$ linked combined immunodeficiencies including $\mathrm{X}$ linked severe combined immunodeficiency (XSCID), ${ }^{4}$ attenuated XSCID, ${ }^{5} \mathrm{X}$ linked combined immunodeficiency with prolonged survival and normal immunoglobulins (XCID), ${ }^{6}$ and the syndrome of cellular immune deficiency with normal immunoglobulins (Nezelof's syndrome) ${ }^{7}$ In our patient, the clinical course, with recurrent respiratory infections and prolonged survival, and the immunological findings are similar to the milder forms of $\mathrm{X}$ linked combined immunodeficiency previously described. ${ }^{67}$ Defective $T$ cell number and function were first noted at $\mathbf{1 1}$ months of age and have worsened with time. B cell numbers are normal, a feature previously noted in both $\mathrm{XCID}^{6}$ and Nezelof's syndrome. ${ }^{7}$ IgM and IgA concentrations have fluctuated; however, isoagglutinin titres have remained low despite normal serum IgM. The low number of $\mathrm{T}$ cells in our patients differs from the findings reported in attenuated XSCID. ${ }^{5}$

The relation between growth hormone and immunodeficiency is unclear. Growth hormone has been implicated to play a part in the development, maintenance, and function of cell mediated immunity. The Snell-Bagg dwarf mouse with hypopituitarism and a thymus dependent immunodeficiency, manifesting as defective cell mediated immunity and partial impairment of humoral immunity in the presence of normal immunoglobulins, is analogous to our patient. Cellular and humoral immunity in these mice has been restored with growth hormone treatment. ${ }^{8}$ Growth hormone replacement in our patient, however, while resulting in an increased growth velocity, did not improve immune function after 11 months. Furthermore, in vitro culture of his lymphocytes with recombinant growth hormone did not improve mitogenic responses. It has recently been suggested that a gene regulating growth hormone production is situated in the mid-portion of the long arm of the $\mathrm{X}$ chromosome. ${ }^{2} \mathrm{~A}$ defect of the $\mathrm{X}$ chromosome involving this gene could account for the $\mathrm{X}$ linked inheritance of a combined immunodeficiency and growth hormone deficiency.

Short stature in children with combined immune deficiency may often be attributed to the effect of recurrent infections. The findings in our patient suggest that growth hormone deficiency should be considered as a possible cause of short stature in children with combined immune deficiencies.

We thank Dr G Werther, department of endocrinology, Roya Children's Hospital, Melbourne, for reviewing this manuscript. Dr Tang was supported by a National Health and Medica Research Council scholarship.

I Fleisher TA, White RM, Broder S, et al. X-linked hypogammaglobulinaemia and isolated growth hormone gammaglobulinaemia and isolated growt

2 Conley ME, Burks AW, Herrod HG, Puck JM. Molecular analysis of X-linked agammaglobulinemia with growth hormone deficiency. F Pediatr 1991;119:392-7.

3 Monafo V, Maghnie M, Terracciano L, Valtorta A, Massa M, Severi F. X-linked agammaglobulinemia and isolated growth hormone deficiency. Acta Pediatr Scand 1991;80: $563-6$.

4 Griscelli C, Durandy A, Virelizier JL, Ballet JJ, Daguillard F. Selective defect of precursor $T$ cells associated with apparently normal B lymphocytes in severe combined apparently normal B lymphocytes in severe com

5 de Saint-Basile G, Le Deist F, Caniglia M, Lebranchu Y, Griscelli C, Fischer A. Genetic study of a new X-linked recessive immunodeficiency syndrome. $\mathcal{f}$ Clin Invest 1992; 89:861-6.

6 Broks EG, Schmalstieg FC Wirt DP et al. A novel $\mathrm{X}$-linked combined immunodeficiency disease. $\mathrm{f}$ Clin X-linked combined imm

7 Lawler GJ Jr, Ammann AJ, Wright WC Jr, La Franchi SH, Bilstrom D, Stiehm ER. The syndrome of cellular immunodeficiency with immunoglobulins. F Pediatr 1974; 84:183-92.

8 Fabris N, Pierpaoli W, Sorkin E. Hormones and the immunological capacity. IV. Restorative effects of developmental hormones or of lymphocytes on the immunodeficiency syndrome of the dwarf mouse. Clin Exp Immunol 1971;9:227-40. 